\title{
CLAB Transuranic Waste Spreadsheets
}

by

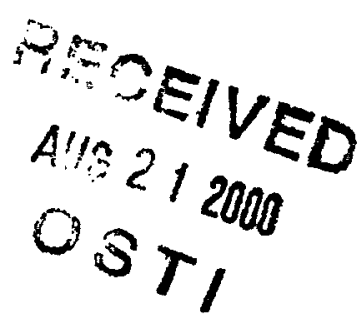

J. D. Leyba

Westinghouse Savannah River Company

Savannah River Site

Aiken, South Carolina 29808

This paper was prepared in connection with work done under the above contract number with the $U$. S. Department of Energy. By acceptance of this paper, the publisher and/or recipient acknowledges the $U$. $S$. Government's right to retain a nonexclusive, royalty-free license in and to any copyright covering this paper, along with the right to reproduce and to authorize others to reproduce all or part of the copyrighted paper. 


\section{WSRC-TR-99-00414}

Revision 0

Kenwords: Assay System Nuclides Spreadsheets - Transuranic

Classification: U

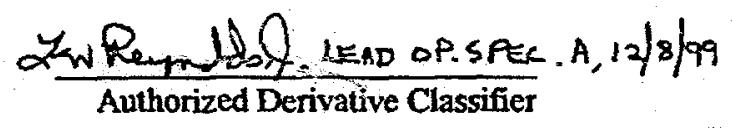

\section{CLAB TRANSURANIC WASTE SPREADSHEETS (U)}

\section{J. D. Leyb:}

Publication Date: Novenber 1, 1999
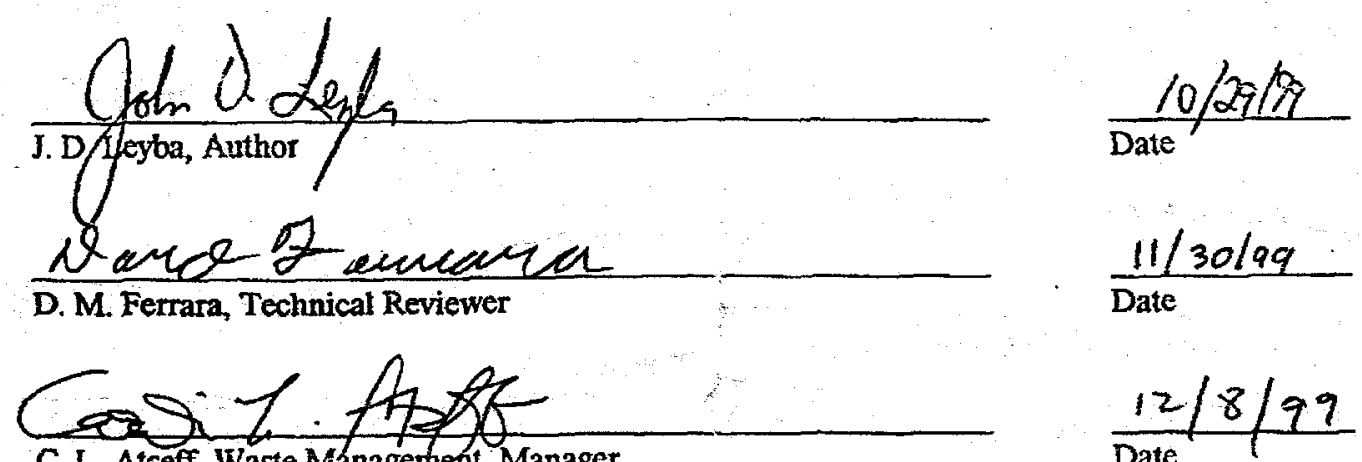

C. L. Atseff, Waste Managenthent Manager

$\frac{12 / 8 / 99}{\text { Date }}$

Westinghouse Savannah River Company

Savannah River Site

Aiken, SC 29808

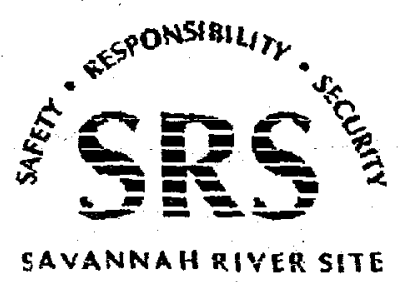




\title{
CLAB TRANSURANIC WASTE SPREADSHEETS (U)
}

\author{
John D. Leyba
}

Unclassified

Does Not Contain Unclassified Controlled Nuclear Information (UCNI)

November, 1, 1999

Westinghouse Savannah River Company

Savannah River Site

Aiken, SC 29808

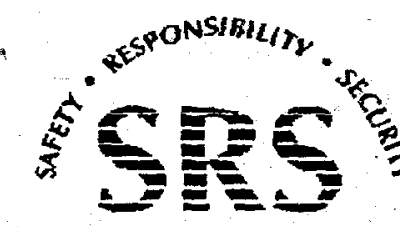




\section{DISCLAIMER}

This report was prepared as an account of work sponsored by an agency of the United States Government. Neither the United States Government nor any agency thereof, nor any of their employees, makes any warranty, express or implied, or assumes any legal liability or responsibility for the accuracy, completeness, or usefulness of any information, apparatus, product or process disclosed, or represents that its use would not infringe privately owned rights. Reference herein to any specific commercial product, process or service by trade name, trademark, manufacturer, or otherwise does not necessarily constitute or imply its endorsement, recommendation, or favoring by the United States Government or any agency thereof. The views and opinions of authors expressed herein do not necessarily state or reflect those of the United States Government or any agency thereof.

This report has been reproduced directly from the best available copy.

Available for sale to the public, in paper, from: U.S. Department of Commerce, National Technical Information Service, 5285 Port Royal Road, Springfield, VA 22161, phone: (800) 553-6847

fax: (703) 605-6900

email: orders@ntis.fedworld.gov

online ordering: http://www.ntis.gov/ordering.htm

Available electronically at http://www.doe.gov/bridge

Available for a processing fee to U.S. Department of Energy and its contractors, in paper, from: U.S. Department of Energy, Office of Scientific and Technical Information, P.O. Box 62, Oak Ridge, TN 37831-0062, phone: (865) 576-8401

fax: (865) 576-5728

email: reports@adonis.osti.gov 


\section{DISCLAIMER}

Portions of this document may be illegible in electronic image products. Images are produced from the best available original document. 


\section{ABSTRACT}

The Building 772-F Far-Field Transuranic (TRU) Waste Counting System is used to measure the radionuclide content of waste packages produced at the Central Laboratory Facilities (CLAB). Data from the instrument are entered into one of two Excel spreadsheets. The waste stream associated with the waste package determines which spreadsheet is actually used. The spreadsheets calculate the necessary information required for completion of the Transuranic Waste Characterization Form (OSR 29-90) and the Radioactive Solid Waste Burial Ground Record (OSR 7-375 or OSR 7-375A). In addition, the spreadsheets calculate the associated Low Level Waste (LLW) stream information that potentially could be useful if the waste container is ever downgraded from TRU to LLW. The spreadsheets also have the capability to sum activities from source material added to a waste container after assay. A validation data set for each spreadsheet along with the appropriate results are also presented in this report for spreadsheet verification prior to each use. 
WSRC-TR-99-00414

Revision 0

November 1, 1999

Page $v$

This page intentionally left blank. 
WSRC-TR-99-00414

Revision 0

November 1, 1999

Page vi

\section{TABLE OF CONTENTS}

1.0 INTRODUCTION

1

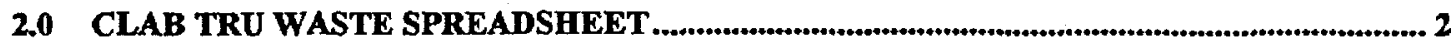

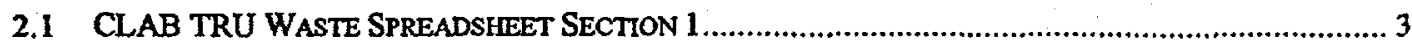

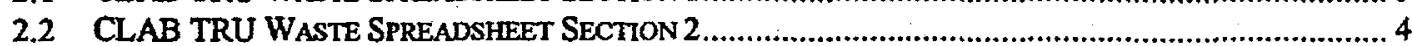

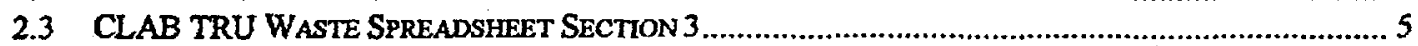

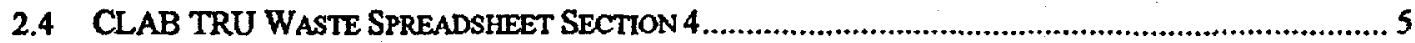

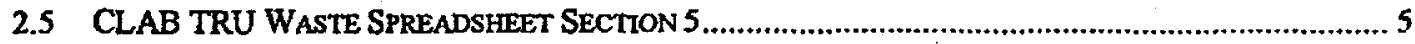

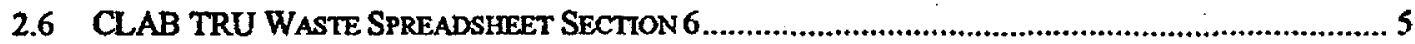

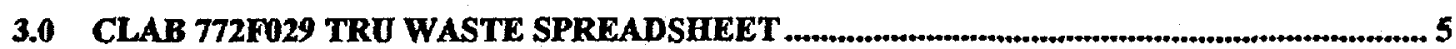

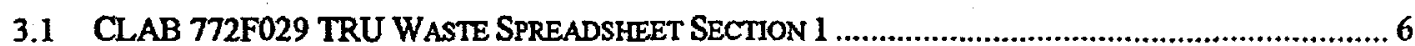

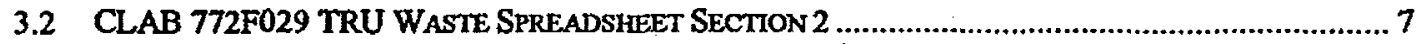

3.3 CLAB 772F029 TRU WASTE SPREADSHEET SECTION 3 …......................................................... 8

3.4 CLAB 772F029 TRU WASTE SPREADSHEET SECTION 4 …................................................. 8

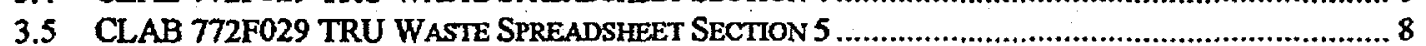

3.6 CLAB 772F029 TRU WASTE SPREADSHEET SECTION 6 ...................................................... 8

4.0 SPREADSHEET VALIDATION PRIOR TO EACH USE..................................................... 8

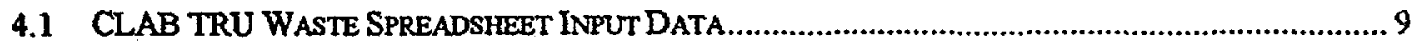

4.2 CLAB TRU WASTE SPREADSHEET ANALYTICAL METHODS \& COMPUTATIONS ............................... 9

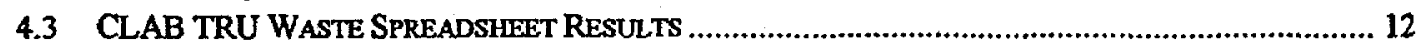

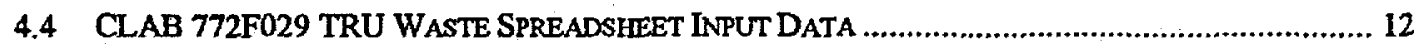

4.5 CLAB 772F029 TRU WASTE SPREADSHEET ANALYTICAL METHODS \& COMPUTATIONS.............. 12

4.6 CLAB 772F029 TRU WASTE SPREADSHEET RESULTS............................................................ 14

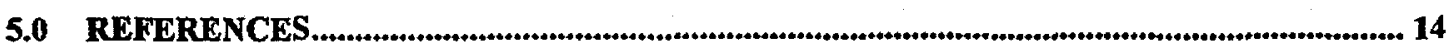

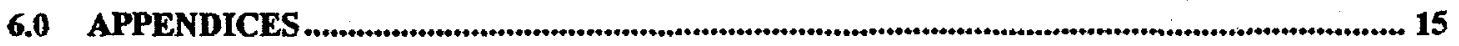

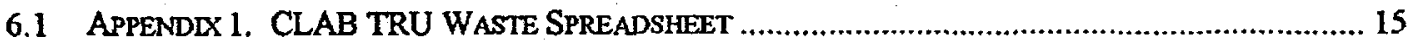

6.2 APPENDXX 2. CLAB 772F029 TRU SPREADSHEET .......................................................... 15

\section{LIST OF TABLES}

Table 1. TRU Waste Distribution .................................................................................. 1

Table 2. 772F029 Waste Distribution ..................................................................... 2

Table 3. LLW Distribution for CLAB TRU Waste Distribution ................................. 3

Table 4. LLW Distribution for CLAB 772F029 TRU Waste Distribution.................. 6

Table 5. CLAB TRU Waste Spreadsheet Input Data ...............................................9

Table 6. CLAB 772F029 TRU Waste Spreadsheet Input Data ................................. 12 
WSRC-TR-99-00414

Revision 0

November 1, 1999

Page vii

\section{LIST OF ACRONYMS USED}

CLAB - Central Laboratory Facilities

CTF Cognizant Technical Function

LLW Low Level Waste

TRU Transuranic 


\title{
CLAB TRANSURANIC WASTE SPREADSHEETS (U)
}

\author{
J. D. Leyba \\ Westinghouse Savannah River Company \\ Savannah River Site. \\ Aiken, SC 29808
}

\subsection{INTRODUCTION}

Activities performed at CLAB generate TRU waste that must be assayed in order to conservatively estimate the quantity of TRU nuclides contained in the waste. The TRU waste is assayed in 55-gallon drum liners using the 772-F Far Field Transuranic Waste Counting System [1]. This assay system is a low level, gamma pulse height analysis system that uses a single high-purity germanium detector. After a waste package is weighed, it is placed on a turntable that rotates during assay. A transmission source is also employed on the system in order to correct for the effect of sample density on gamma ray attenuation. Currently, the data acquisition system is a Canberra Series 90 Multichannel Analyzer linked to a VAX computer. However, the data acquisition system will soon be upgraded to an Ortec PC-based system. TRU waste assayed on the 772-F Far Field Transuranic Waste Counting System can be from one of two distributions, TRU and 772F029. Descriptions of these two distributions are given in Tables 1 and 2 respectively [1].

Table 1. TRU Waste Distribution

\begin{tabular}{|c|c|c|}
\hline Nuclide & Basis Nuclide & Scaling Factor \\
\hline Co-60 & Directly Measured & N/A \\
\hline Cs-137 & Directly Measured & N/A \\
\hline U-235 & Directly Measured & N/A \\
\hline Np-237 & Directly Measured & N/A \\
\hline Pu-238 & Directly Measured & N/A \\
\hline Pu-239 & Directly Measured & N/A \\
\hline Pu-240 & Pu-239 & $3.62 \mathrm{E}-01$ \\
\hline Pu-241 & Pu-239 & $1.57 \mathrm{E}+01$ \\
\hline Am-241 & Directly Measured & N/A \\
\hline Pu-242 & Pu-239 & $2.64 \mathrm{E}-04$ \\
\hline
\end{tabular}


Table 2. 772F029 Waste Distribution

\begin{tabular}{|c|c|c|}
\hline Nuclide & Basis Nuclide & Scaling Factor \\
\hline U-235 & Directly Measured & N/A \\
\hline Np-237 & Directly Measured/U-235 & $2.09 \mathrm{E}-02$ \\
\hline Pu-242 & U-235 & $1.09 \mathrm{E}+01$ \\
\hline Am-243 & U-235 & $2.36 \mathrm{E}+00$ \\
\hline Cm-244 & U-235 & $7.64 \mathrm{E}+01$ \\
\hline
\end{tabular}

As shown in Table 2 for the 772F029 distribution, Np-237 is directly measured by the assay system. However, if it is not detected in a waste package, then this nuclide is scaled to U-235 using the listed scaling factor. Unidentified peaks not listed in the libraries can be identified based upon peak energy and the associated nuclide(s) can subsequently be quantified based upon known gamma ray intensities. Thus, when gamma-emitting nuclides are present which are not ordinarily expected, they can easily be quantified.

\subsection{CLAB TRU WASTE SPREADSHEET}

The CLAB TRU Waste Spreadsheet is an Excel spreadsheet used to calculate essential values necessary for the completion of the Transuranic Waste Characterization Form (OSR 29-90) and the Radioactive Solid Waste Burial Ground Record (OSR 7-375 or OSR 7-375A). In addition, this spreadsheet calculates the associated LLW stream information that could potentially be useful if the waste container is ever downgraded from TRU to LLW. Table 3 lists the nuclides, basis nuclides, and scaling factors for the LLW waste stream distribution developed for the CLAB TRU waste stream [1]. As shown in Table 3 for the LLW distribution associated with the CLAB TRU distribution, C0.60 is directly measured by the assay system. However, if this nuclide is not present, it is scaled to Cs-137 using the listed scaling factor.

The CLAB TRU Waste Spreadsheet is divided into six sections that are described below. Input is required only for section 1 and is optional for section 2 . The spreadsheet uses the data from sections 1 and 2 to calculate the necessary values for sections 3-5. Section 6 is used for documenting verification of spreadsheet integrity prior to use and verification of input data. All cells performing critical functions such as calculations are password protected by the Cognizant Technical Function (CTF). 
Table 3. LLW Distribution for CLAB TRU Waste Distribution

\begin{tabular}{|c|c|c|}
\hline Nuclide & Basis Nuclide & Scaling Factor \\
\hline $\mathrm{H}-3$ & $\mathrm{Cs}-137$ & $8.57 \mathrm{E}-04$ \\
\hline $\mathrm{C}-14$ & Cs-137 & $3.13 \mathrm{E}-10$ \\
\hline $\mathrm{Ni}-59$ & Cs-137 & $3.13 \mathrm{E}-10$ \\
\hline Co-60 & Directly Measured/Cs-137 & $3.78 \mathrm{E}-02$ \\
\hline Sr-90 & Cs-137 & 9.77E-01 \\
\hline$Y-90$ & $\mathrm{Cs}-137$ & 9.77E-01 \\
\hline Tc-99 & Cs-137 & $1.93 \mathrm{E}-04$ \\
\hline $\mathrm{I}-129$ & Cs-137 & $3.11 \mathrm{E}-07$ \\
\hline Cs-137 & Directly Measured & N/A \\
\hline $\mathrm{Ba}-137 \mathrm{~m}$ & Cs-137 & $9.46 \mathrm{E}-01$ \\
\hline $\mathrm{Pm}-147$ & $\mathrm{Cs}-137$ & $6.24 \mathrm{E}-02$ \\
\hline Cs-134 & $\mathrm{Cs}-137$ & $6.29 \mathrm{E}-03$ \\
\hline Other beta/gamma & $\mathrm{Cs}-137$ & 4.10E-02 \\
\hline $\mathrm{Np}-237$ & Directly Measured & $\mathrm{N} / \mathrm{A}$ \\
\hline Am-241 & Directly Measured & N/A \\
\hline $\mathrm{U}-234$ & $\mathrm{U}-235$ & $6.08 \mathrm{E}+01$ \\
\hline $\mathrm{U}-235$ & Directly Measured & N/A \\
\hline $\mathrm{U}-236$ & U-235 & $1.14 \mathrm{E}+01$ \\
\hline $\mathrm{U}-238$ & $\mathrm{U}-235$ & $3.19 \mathrm{E}-02$ \\
\hline $\mathrm{Pu}-238$ & Directly Measured & N/A \\
\hline $\mathrm{Pu}-239$ & Directly Measured & $N / A$ \\
\hline $\mathrm{Pu}-240$ & Pu-239 & $3.62 \mathrm{E}-01$ \\
\hline $\mathrm{Pu}-241$ & $\mathbf{P u}-239$ & $1.57 \mathrm{E}+01$ \\
\hline $\mathrm{Pu}-242$ & $\mathbf{P u - 2 3 9}$ & $2.64 \mathrm{E}-04$ \\
\hline
\end{tabular}

\subsection{CLAB TRU Waste Spreadsheet Section 1}

Appendix 1 contains an example CLAB TRU Waste Spreadsheet. The header information given at the top of the first page includes the title of the spreadsheet, the spreadsheet version number (and date of version), drum vent number, gress weight of the container (in pounds), net weight (in pounds), net weight (in g), and the error associated with the measurement. The user is required to input the drum vent number and gross weight. The CTF can change the error value from the default $15 \%$ if desired. If this is done, a warning message is generated in the "Comments" section of the first page that will ask for an explanation. Likewise, the CTF may change the default scaling factors if desired. If this is done, a waming message will be generated in the "Comments" section asking for an explanation.

Below the header information are eleven columns labeled, "Nuclide", "Scaling Factor", "Specific Activity Ci/g", "Measured Activity nCi", "Detection Limit? (Y or N)", "Reported 
Activity nCi", "2X Error nCi", "Mass grams", "2X Error Mass grams", "Measured TRU Content nCi/g", and "Reportable TRU Content nCi/g". These column headings represent the name of the nuclide; the scaling factor associated with the nuclide; the specific activity of the nuclide (in $\mathrm{Ci} / \mathrm{g}$ ); the measured activity of the nuclide from the waste counting system (in nCi); whether or not the measured activity represents a detection limit; the activity value to be reported (in $\mathrm{nCi}$ ); the 2 -sigma error of the reported activity (in $\mathrm{nCi}$ ); the mass (in g) of the nuclide based upon the reported activity; the 2-sigma error (in g) associated with the mass; the TRU content (in $\mathrm{nCi} / \mathrm{g}$ ) of those TRU nuclides which were not scaled and were actually detected in the waste package; and finally, the TRU content (in $\mathrm{nCi} / \mathrm{g}$ ) of the waste package based upon all TRU nuclides in the library. Thus, this final column gives the TRU contribution of scaled and directly measured nuclides, including detection limit values for nuclides that were assayed for but not found.

All of the nuclides included in the CLAB TRU library are listed in section 1 of the TRU spreadsheet. Gamma-emitting nuclides detected in a waste package that are not in the TRU library can be added in section 1 (in the "Other Nuclides Detected" portion) so that their contribution to the waste package can be included in the necessary calculations. If any of these additional nuclides are TRU, their contribution to the TRU package content can be entered into the "Total of Other TRU Nuclides Identified" cell. The spreadsheet then automatically calculates the total TRU content (in $\mathrm{nCi} / \mathrm{g}$ ) of the waste package and displays this value in the cell labeled "TRU Grand Total". In order for the spreadsheet to calculate the necessary parameters for the "Other Nuclides Detected" portion of the spreadsheet, the user must input the nuclide, whether or not (yes or no) the nuclide is listed on form OSR 29-90, the specific activity (in $\mathrm{Ci} / \mathrm{g}$ ) of the nuclide, the measured activity of the nuclide from the waste counting system (in $\mathrm{nCi}$ ), and the 2-sigma error (in $\mathrm{nCi})$ associated with the measured activity value. The spreadsheet will subsequently calculate the mass and 2-sigma error (in $\mathrm{g}$ ) of the other nuclide(s) along with the measured activity (in $\mathrm{Ci}$ and in $\mathrm{nCi} / \mathrm{g}$ ). It is recommended that specific activity values be taken from Reference 2.

\subsection{CLAB TRU Waste Spreadsheet Section 2}

Section 2 of the CLAB TRU Waste Spreadsheet contains information regarding Pu-238 and $\mathrm{Pu}-239$ sources that may be added to a waste package after it is assayed. The spreadsheet allows up to three $\mathrm{Pu}-238$ sources and three $\mathrm{Pu}-239$ sources to be entered. The user must enter the source id, the mass (in g) of material (Pu-238 or Pu-239) contained in the source, and the 2-sigma error (in $\mathrm{g}$ ) associated with the mass value. Subsequently, the spreadsheet automatically and separately sums the masses of all $\mathrm{Pu}-238$ sources and $\mathrm{Pu}-239$ sources and calculates the total error associated with each sum. For example, assume one has two sources containing $g_{1} \pm \sigma_{1}$ and $g_{2} \pm \sigma_{2}$ where $g_{1}$ and $g_{2}$ are the masses of source one and two respectively and $\sigma_{1}$ and $\sigma_{2}$ are the 2-sigma errors respectively. The sum of the masses and the associated error would be $\left(g_{1}+g_{2}\right) \pm$ $\left(\sigma_{1}{ }^{2}+\sigma_{2}{ }^{2}\right)^{1 / 2}[3]$. 


\subsection{CLAB TRU Waste Spreadsheet Section 3}

Section 3 of the CLAB TRU Waste Spreadsheet calculates the total mass (in g) and the associated 2-sigma error (in g) of the eight nuclides contained in the TRU library which are listed on form OSR 29-90. The total mass values and 2-sigma errors for Pu-238 and $\mathrm{Pu}-239$ include contributions from added sources that are listed in section 2 . Additionally, if any nuclides were entered under "Other Nuclides Detected" in section 1 of the spreadsheet, these nuclides will also be listed in section 3 along with the masses and associated 2-sigma uncertainties. A message ("The mass value is based upon a detection limit.") will be listed in the "Comments" column if the listed mass value is based upon a detection limit.

\subsection{CLAB TRU Waste Spreadsheet Section 4}

Information relating to the Burial Ground Record (OSR 7-375 or OSR 7-375A) is calculated in section 4 of the CLAB TRU Waste Spreadsheet. This section is separated by material type and includes Pu-239, Pu-238, Am-241, Np-237, and U-235. For each material type the spreadsheet has a default distribution and/or scaling factors. The spreadsheet uses the scaling factors to calculate the mass and 2-sigma error for each nuclide in the distribution for the purpose of OSR 7-375 or OSR 7-375A reporting.

\subsection{CLAB TRU Waste Spreadsheet Section 5}

The associated low level waste distribution information for the waste package is calculated in section 5 . The section calculates the reported activity in $\mathrm{nCi}$ and $\mathrm{Ci}$. See Table 3 for more details of this distribution.

\subsection{CLAB TRU Waste Spreadsheet Section 6}

Section 6 contains two signature/date lines for spreadsheet approval. One line is used for documenting verification of spreadsheet integrity while the other line is used to document data input verification. See section 4.0 for more details on the use of these two signature lines.

\subsection{CLAB 772F029 TRU WASTE SPREADSHEET}

The CLAB 772F029 TRU Waste Spreadsheet is an Excel spreadsheet used to calculate essential values necessary for the completion of the Transuranic Waste Characterization Form (OSR 29-90) and the Radioactive Solid Waste Burial Ground Record (OSR 7-375 or OSR 7-375A). In addition, this spreadsheet calculates the associated LLW stream information that could potentially be useful if the waste container is ever downgraded from TRU to LLW. Table 4 lists the nuclides, basis nuclides, and scaling factors for the LLW waste stream distribution developed for the CLAB. 772F029 TRU waste stream [1]. 
Table 4. LLW Distribution for CLAB 772F029 TRU Waste Distribution

\begin{tabular}{|c|c|c|}
\hline Nuclide & Basis Nuclide & Scaling Factor \\
\hline H-3 & Cs-137 & $8.57 \mathrm{E}-04$ \\
\hline C-14 & Cs-137 & $3.13 \mathrm{E}-10$ \\
\hline Co-60 & Cs-137 & $3.13 \mathrm{E}-10$ \\
\hline Sr-90 & Directly Measured/Cs-137 & $3.78 \mathrm{E}-02$ \\
\hline Y-90 & Cs-137 & $9.77 \mathrm{E}-01$ \\
\hline Tc-99 & Cs-137 & $9.77 \mathrm{E}-01$ \\
\hline I-129 & Cs-137 & $1.93 \mathrm{E}-04$ \\
\hline Cs-137 & Cs-137 & $3.11 \mathrm{E}-07$ \\
\hline Ba-137m & Directly Measured & N/A \\
\hline Pm-147 & Cs-137 & $9.46 \mathrm{E}-01$ \\
\hline Cs-134 & Cs-137 & $6.24 \mathrm{E}-02$ \\
\hline Other beta/gamma & Cs-137 & $6.29 \mathrm{E}-03$ \\
\hline U-235 & Cs-137 & $4.10 \mathrm{E}-02$ \\
\hline Np-237 & Directly Measured & N/A \\
\hline
\end{tabular}

As shown in Table 4 for the 772F029 TRU distribution, Co-60 is directly measured by the assay system. However, if this nuclide is not present, it is scaled to Cs-137 using the listed scaling factor.

The CLAB 772F029 TRU Waste Spreadsheet is divided into six sections that are described below. Input is required only for section 1 and is optional for section 2 . The spreadsheet uses the data from sections 1 and 2 to calculate the necessary values for sections 3-5. Section 6 is used for documenting verification of spreadsheet integrity prior to use and verification of input data. All cells performing critical functions such as calculations are password protected by the CTF.

\subsection{CLAB 772F029 TRU Waste Spreadsheet Section 1}

Appendix 2 contains an example CLAB 772F029 TRU Waste Spreadsheet. The header information given at the top of the first page includes the title of the spreadsheet, the spreadsheet version number (and date of version), drum vent number, gross weight of the container (in pounds), net weight (in pounds), net weight (in g), and the error associated with the measurement. The user is required to input the drum vent number and gross weight. The CTF can change the error value from the default $15 \%$ if desired. If this is done, a warning message is generated in the "Comments" section of the first page that will ask for an explanation. Likewise, the CTF may change the default scaling factors if desired. If this is done, a warning message will be generated in the "Comments" section asking for an explanation. 
Below the header information are eleven columns labeled, "Nuclide", "Scaling Factor", "Specific Activity Ci/g", "Measured Activity nCi", "Detection Limit? (Y or N)", "Reported Activity nCi", "2X Error nCi", "Mass grams", "2X Error Mass grams", "Measured TRU Content $\mathrm{nCi} / \mathrm{g}$ ", and "Reportable TRU Content $\mathrm{nCi} / \mathrm{g}$ ". These column headings represent the name of the nuclide; the scaling factor associated with the nuclide; the specific activity of the nuclide (in $\mathrm{Ci} / \mathrm{g}$ ); the measured activity of the nuclide from the waste counting system (in nCi); whether or not the measured activity represents a detection limit; the activity value to be reported (in $\mathrm{nCi}$ ); the 2 -sigma error of the reported activity (in $\mathrm{nCi}$ ); the mass (in $\mathrm{g}$ ) of the nuclide based upon the reported activity; the 2-sigma error (in $\mathrm{g}$ ) associated with the mass; the TRU content (in $\mathrm{nCi} / \mathrm{g}$ ) of those TRU nuclides which were not scaled and were actually detected in the waste package; and finally, the TRU content (in $\mathrm{nCi} / \mathrm{g}$ ) of the waste package based upon all TRU nuclides in the library. Thus, this final column gives the TRU contribution of scaled and directly measured nuclides, including detection limit values for nuclides that were assayed for but not found.

All of the nuclides included in the 772F029 TRU library are listed in section 1 of the TRU spreadsheet. Gamma-emitting nuclides detected in a waste package that are not in the TRU library can be added in section 1 (in the "Other Nuclides Detected" portion) so that their contribution to the waste package can be included in the necessary calculations. If any of these additional nuclides are TRU, their contribution to the TRU package content can be entered into the "Total of Other TRU Nuclides Identified" cell. The spreadsheet then automatically calculates the total TRU content (in $\mathrm{nCi} / \mathrm{g}$ ) of the waste package and displays this value in the cell labeled "TRU Grand Total". In order for the spreadsheet to calculate the necessary parameters for the "Other Nuclides Detected" portion of the spreadsheet, the user must input the nuclide, whether or not (yes or no) the nuclide is listed on form OSR 29-90, the specific activity (in Ci/g) of the nuclide, the measured activity of the nuclide from the waste counting system (in $\mathrm{nCi}$ ), and the 2-sigma error (in nCi) associated with the measured activity value. The spreadsheet will subsequently calculate the mass and 2-sigma error (in $\mathrm{g}$ ) of the other nuclide(s) along with the measured activity (in $\mathrm{Ci}$ and in $\mathrm{nCi} / \mathrm{g}$ ). It is recommended that specific activity values be taken from Reference 2.

\subsection{CLAB 772F029 TRU Waste Spreadsheet Section 2}

Section 2 of the CLAB 772 F029 TRU Waste Spreadsheet contains information regarding $\mathrm{Pu}-238$ and Pu-239 sources that may be added to a waste package after it is assayed. The spreadsheet allows up to three $\mathrm{Pu}-238$ sources and $3 \mathrm{Pu}-239$ sources to be entered. The user must enter the source id, the mass (in g) of material (Pu-238 or Pu-239) contained in the source, and the 2-sigma error (in g) associated with the mass value. Subsequently, the spreadsheet automatically and separately sums the masses of all $\mathrm{Pu}-238$ sources and $\mathrm{Pu}$ 239 sources and calculates the total error associated with each sum. For example, assume one has two sources containing $g_{1} \pm \sigma_{1}$ and $g_{2} \pm \sigma_{2}$ where $g_{1}$ and $g_{2}$ are the masses of 
source one and two respectively and $\sigma_{1}$ and $\sigma_{2}$ are the 2-sigma errors respectively. The sum of the masses and the associated error would be $\left(g_{1}+g_{2}\right) \pm\left(\sigma_{1}{ }^{2}+\sigma_{2}{ }^{2}\right)^{1 / 2}[3]$.

\subsection{CLAB 772F029 TRU Waste Spreadsheet Section 3}

Section 3 of the CLAB 772F029 TRU Waste Spreadsheet calculates the total mass (in g) and the associated 2-sigma error (in g) of the five nuclides contained in the 772F029 TRU library (and Pu-238 \& Pu-239) which are listed on form OSR 29-90. Additionally, if any nuclides were entered under "Other Nuclides Detected" in section 1 of the spreadsheet, these nuclides will also be listed in section 3 along with the masses and associated 2-sigma uncertainties. A message ("The mass value is based upon a detection limit.") will be listed in the "Comments" column if the listed mass value is based upon a detection limit.

\subsection{CLAB 772F029 TRU Waste Spreadsheet Section 4}

Information relating to the Burial Ground Record (OSR 7-375 or OSR 7-375A) is calculated in section 4 of the CLAB 772F029 TRU Waste Spreadsheet. This section is separated by material type and includes Pu-239, Pu-238, Am-243, Np-237, and U-235. For each material type the spreadsheet has a default distribution and/or scaling factors. The spreadsheet uses the scaling factors to calculate the mass and 2-sigma error for each nuclide in the distribution for the purpose of OSR 7-375 or OSR 7-375A reporting.

\subsection{CLAB 772F029 TRU Waste Spreadsheet Section 5}

The associated low level waste distribution information for the waste package is calculated in section 5. The section calculates the reported activity in $\mathrm{nCi}$ and $\mathrm{Ci}$. See Table 4 for more details regarding this distribution.

\subsection{CLAB 772F029 TRU Waste Spreadsheet Section 6}

Section 6 contains two signature/date lines for spreadsheet approval. One line is used for documenting verification of spreadsheet integrity while the other line is used to document data input verification. See section 4.0 for more details on the use of these two signature lines.

\subsection{SPREADSHEET VALIDATION PRIOR TO EACH USE}

A set of test data has been developed for input into the CLAB TRU Waste Spreadsheet and a data set has been developed for the CLAB 772F029 TRU Spreadsheet before each use to ensure that the integrity has not been compromised. These data sets consist of several nuclides at various activity levels. 
After inputting the test data, the user compares the results of the open spreadsheet with those given in either Appendix 1 or Appendix 2 of this document. If the results are identical, the spreadsheet is considered verified and can be used for actual data after a copy of the spreadsheet is signed and dated on the "Spreadsheet Integrity Verification" line. If the results are not identical, the CTF and/or designee will investigate the discrepancy and take the appropriate corrective action.

\subsection{CLAB TRU Waste Spreadsheet Input Data}

An example CLAB TRU Waste Spreadsheet with the verification data is shown in Appendix 1. The number of the drum vent which will be associated with the actual waste package should be entered in the "Drum Vent \#" cell. For verification purposes, the gross weight should be entered as 45 pounds. The remainder of the verification input data is summarized in Table 5.

Table 5. CLAB TRU Waste Spreadsheet Input Data

\begin{tabular}{|c|c|c|}
\hline Nuclide & Measured Activity & Detection Limit? \\
\hline $\mathrm{U}-235$ & $1.000 \mathrm{E}+04 \mathrm{nCi}$ & $\mathrm{N}$ \\
\hline $\mathrm{Np}-237$ & $1.000 \mathrm{E}+04 \mathrm{nCi}$ & $\mathrm{N}$ \\
\hline $\mathrm{Pu}-238$ & $1.000 \mathrm{E}+08 \mathrm{nCi}$ & $\mathrm{N}$ \\
\hline $\mathrm{Pu}-239$ & $1.000 \mathrm{E}+06 \mathrm{nCi}$ & $\mathrm{N}$ \\
\hline $\mathrm{Am}-241$ & $1.000 \mathrm{E}+04 \mathrm{nCi}$ & $\mathrm{N}$ \\
\hline $\mathrm{Co}-60$ & $1.000 \mathrm{E}+04 \mathrm{nCi}$ & $\mathrm{N}$ \\
\hline $\mathrm{Cs}-137$ & $1.000 \mathrm{E}+04 \mathrm{nCi}$ & $\mathrm{N}$ \\
\hline
\end{tabular}

Only the data above needs to be entered in order to verify the spreadsheet. All other values necessary to perform the calculations are already in the spreadsheet in locked cells.

Once entered, the results of the spreadsheet are compared with the results given in Appendix 1 of this document. If all of the results agree exactly, the spreadsheet is considered verified. The verified spreadsheet is then printed, signed, and dated by the verifier for records retention purposes. If discrepancies are found, the user must verify that the input data is correctly entered. If the input data are found to be correctly entered and there is still a discrepancy, the spreadsheet is not used and the CTF or designee is notified for corrective action.

\subsection{CLAB TRU Waste Spreadsheet Analytical Methods \& Computations}

As an illustration of the methodology used to perform the calculations in the spreadsheet, U-235 will be used as an example. The "Measured Activity" value is taken from the assay instrument report and is entered by the user. In addition, if the measured value is a detection limit, then " $Y$ " is entered in the "Detection Limit?" column, otherwise, "N" is entered. The "Reported Activity" value in section 1 is determined by the spreadsheet and is simply the measured activity (or detection limit value) if the nuclide is actually 
measured; or if the nuclide is scaled, this value is calculated by taking the product of the basis nuclide and the appropriate scaling factor. There are three scaled nuclides $\mathbf{P u}-240$, $\mathrm{Pu}-241$, and $\mathrm{Pu}-242$ ) in this spreadsheet and all three are scaled to the $\mathrm{Pu}-239$ activity.

The "2X Error" value is calculated by taking twice the measurement error and multiplying it by the reported activity. The measurement error by default is set at $15 \%$; however, the CTF may change this value with the appropriate technical justification. Using U-235 as an example,

\section{U-235 2X Error $(n C i)=1.000 E+04 \times(2 \times 0.15)=3.000 E+03$.}

The mass value for a given nuclide is calculated by dividing the reported activity by the specific activity. The reported activity must first be converted to the proper units, however. Once again, using U-235 as the example,

$\mathrm{U}-235$ reported activity $(\mathrm{Ci})=1.000 \mathrm{E}+04 \mathrm{nCi} \times \frac{1 \mathrm{Ci}}{1 \mathrm{E}+09 \mathrm{nCi}}=1.000 \mathrm{E}-05$

$\mathrm{U}-235$ mass $(\mathrm{g})=\frac{1.000 \mathrm{E}-05 \mathrm{Ci}}{2.16 \mathrm{E}-06 \frac{\mathrm{Ci}}{\mathrm{g}}}=4.630 \mathrm{E}+00$.

The "2X Error" value associated with the mass is calculated by taking the "2X Error" value (in $\mathrm{nCi}$ ), converting it to the proper units, and dividing by the specific activity.

$\mathrm{U}-2352 \mathrm{X}$ error $(\mathrm{Ci})=3.000 \mathrm{E}+03 \mathrm{nCi} \times \frac{1 \mathrm{Ci}}{1 \mathrm{E}+09 \mathrm{nCi}}=3.000 \mathrm{E}-06$

$\mathrm{U}-235 \operatorname{mass}(\mathrm{g})=\frac{3.000 \mathrm{E}-06 \mathrm{Ci}}{2.16 \mathrm{E}-06 \frac{\mathrm{Ci}}{\mathrm{g}}}=1.389 \mathrm{E}+00$

The "Measured TRU Content" value is calculated by taking the reported activity (in nCi) and dividing by the net weight (in g) of the waste package. This calculation only applies to gamma-emitting TRU nuclides contained in the CLAB TRU library that are actually detected. The calculation is not applicable to U-235 since this nuclide is not transuranic. Thus, this column is applicable to only four nuclides (Np-237, Pu-238, Pu-239, and Am241 ) in the verification data set. Therefore, the measured TRU content (in $\mathrm{nCi} / \mathrm{g}$ ) is

$n C i / g$ TRU $=(\mathrm{Np}-237)+(\mathrm{Pu}-238)+(\mathrm{Pu}-239)+(\mathrm{Am}-241)$

$\mathrm{nCi} / \mathrm{g} \mathrm{TRU}=8.165 \mathrm{E}-01+8.165 \mathrm{E}+03+8.165 \mathrm{E}+01+8.165 \mathrm{E}-01$ 
nCi/g TRU $=8.249 \mathrm{E}+03$.

The "Reportable TRU Content" value is calculated by taking the reported activity (in nCi) and dividing by the net weight (in g) of the waste package. This calculation is applicable to all TRU nuclides that are in the CLAB TRU library.

No information is required to be entered into section 2 for spreadsheet verification. This section was described previously in section 2.2 of this report. In addition, the spreadsheet automatically transfers the mass values and associated errors to the appropriate cells in section 3 of the spreadsheet.

Section 4 of the spreadsheet calculates the Burial Ground Record information for the various types of material that could potentially be present in a waste package. The spreadsheet automatically transfers the "Reportable Mass" value and "2X Error" value to the appropriate cells in section 4 . Using the U-235 material as the example, the reportable masses are calculated for the three other uranium isotopes by multiplying the appropriate scaling factor by the reportable U-235 mass value. For example,

$\mathrm{U}-234$ reportable mass $(\mathrm{g})=60.8000 \times 4.630 \mathrm{~g}=281.5 \mathrm{~g}$.

The $2 \mathrm{X}$ errors for these nuclides are calculated assuming the same $15 \%$ measurement error (1-sigma). This assumption is justified since the other nuclides are scaled from $U$ 235 which has an uncertainty of $15 \%$.

$$
\mathrm{U}-2342 \mathrm{X} \text { error }(\mathrm{g})=281.481 \mathrm{~g} \times \frac{1.389 \mathrm{~g}}{4.630 \mathrm{~g}}=84.444 \mathrm{~g}
$$

The element weight for the uranium material is calculated by summing the weights of the four uranium isotopes listed.

Element Wt $(\mathrm{g})=\mathrm{U}-234+\mathrm{U}-235+\mathrm{U}-236+\mathrm{U}-238$

Element Wt $(\mathrm{g})=281.481+4.630+52.778+0.148=339.037$

The element weight including the $2 \mathrm{X}$ error is calculated assuming that the overall 1 -sigma measurement uncertainty is $15 \%$.

Element Wt $(\mathrm{g})+2 \mathrm{X}$ Error $(\mathrm{g})=339.037+[(2 \times 0.15) \times 339.037]=440.748$.

The associated low level waste distribution shown in section 5 of the spreadsheet is automatically calculated based upon the information entered in sections 1 and 2 . More information on this distribution is given in Table 3. The "Reported Activity" values follow the appropriate reporting rules set forth in Reference 4. As mentioned previously in 
section 2.0 , if Co-60 is not detected, then the reported activity value for this nuclide is scaled to the Cs-137 activity.

\subsection{CLAB TRU Waste Spreadsheet Results}

The CLAB TRU Waste Spreadsheet verification results are shown in Appendix 1.

\subsection{CLAB 772F029 TRU Waste Spreadsheet Input Data}

An example CLAB 772F029 TRU Waste Spreadsheet with the verification data is shown in Appendix 2. The number of the drum vent which will be associated with the actual waste package should be entered in the "Drum Vent \#" cell. For verification purposes, the gross weight should be entered as 45 pounds. The remainder of the verification input data is summarized in Table 6.

Table 6. CLAB 772F029 TRU Waste Spreadsheet Input Data

\begin{tabular}{|c|c|c|}
\hline Nuclide & Measured Activity & Detection Limit? \\
\hline $\mathrm{U}-235$ & $1.000 \mathrm{E}+04 \mathrm{nCi}$ & $\mathrm{N}$ \\
\hline $\mathrm{Np}-237$ & $1.000 \mathrm{E}+04 \mathrm{nCi}$ & $\mathrm{N}$ \\
\hline $\mathrm{Co}-60$ & $1.000 \mathrm{E}+04 \mathrm{nCi}$ & $\mathrm{N}$ \\
\hline $\mathrm{Cs}-137$ & $1.000 \mathrm{E}+04 \mathrm{nCi}$ & $\mathrm{N}$ \\
\hline
\end{tabular}

Only the data above needs to be entered in order to verify the spreadsheet. All other values necessary to perform the calculations are already in the spreadsheet in locked cells.

Once entered, the results of the spreadsheet are compared with the results given in Appendix 2 of this document. If all of the results agree exactly, the spreadsheet is considered verified. The verified spreadsheet is then printed, signed, and dated by the verifier for records retention purposes. If discrepancies are found, the user must verify that the input data is correctly entered. If the input data are found to be correctly entered and there is still a discrepancy, the spreadsheet is not used and the CTF or designee is notified for corrective action.

\subsection{CLAB 772F029 TRU Waste Spreadsheet Analytical Methods \& Computations}

As an illustration of the methodology used to perform the calculations in the spreadsheet, U-235 will be used as an example. The "Measured Activity" value is taken from the assay instrument report and is entered by the user. In addition, if the measured value is a detection limit, then " $Y$ " is entered in the "Detection Limit?" column, otherwise, " $N$ " is entered. The "Reported Activity" value in section 1 is determined by the spreadsheet and is simply the measured activity (or detection limit value) if the nuclide is actually measured; or if the nuclide is scaled, this value is calculated by taking the product of the 
basis nuclide and the appropriate scaling factor. There are three scaled nuclides ( $\mathrm{Pu}-242$, Am-243, and Cm-244) in this spreadsheet and all three are scaled to the U-235 activity. In addition, if $\mathrm{Np}-237$ is not detected, it is also scaled to the U-235 activity.

The "2X Error" value is calculated by taking twice the measurement error and multiplying it by the reported activity. The measurement error by default is set at $15 \%$; however, the CTF may change this value with the appropriate technical justification. Using U-235 as an example,

$\mathrm{U}-2352 \mathrm{X}$ Error $(\mathrm{nCi})=1.000 \mathrm{E}+04 \times(2 \times 0.15)=3.000 \mathrm{E}+03$.

The mass value for a given nuclide is calculated by dividing the reported activity by the specific activity. The reported activity must first be converted to the proper units, however. Once again, using U-235 as the example,

$\mathrm{U}-235$ reported activity $(\mathrm{Ci})=1.000 \mathrm{E}+04 \mathrm{nCi} \times \frac{1 \mathrm{Ci}}{1 \mathrm{E}+09 \mathrm{nCi}}=1.000 \mathrm{E}-05$

$\mathrm{U}-235$ mass $(\mathrm{g})=\frac{1.000 \mathrm{E}-05 \mathrm{Ci}}{2.16 \mathrm{E}-06 \frac{\mathrm{Ci}}{\mathrm{g}}}=4.630 \mathrm{E}+00$.

The "2X Error" value associated with the mass is calculated by taking the "2X Error" value (in $\mathrm{nCi}$ ), converting it to the proper units, and dividing by the specific activity.

$\mathrm{U}-2352 \mathrm{X}$ error $(\mathrm{Ci})=3.000 \mathrm{E}+03 \mathrm{nCi} \times \frac{1 \mathrm{Ci}}{1 \mathrm{E}+09 \mathrm{nCi}}=3.000 \mathrm{E}-06$

$\mathrm{U}-235$ mass $(\mathrm{g})=\frac{3.000 \mathrm{E}-06 \mathrm{Ci}}{2.16 \mathrm{E}-06 \frac{\mathrm{Ci}}{\mathrm{g}}}=1.389 \mathrm{E}+00$

The "Measured TRU Content" value is calculated by taking the reported activity (in nCi) and dividing by the net weight (in $g$ ) of the waste package. This calculation only applies to gamma-emitting TRU nuclides contained in the CLAB 772F029 TRU library that are actually detected. For the verification data set, this column is applicable only to $\mathrm{Np}-237$; thus, the measured TRU content (in $\mathrm{nCi} / \mathrm{g}$ ) is equal to the $\mathrm{Np}-237$ value.

The "Reportable TRU Content" value is calculated by taking the reported activity (in nCi) and dividing by the net weight (in g) of the waste package. This calculation is applicable to all TRU nuclides that are in the CLAB 772F029 TRU library. 
No information is required to be entered into section 2 for spreadsheet verification. This section was described previously in section 3.2 of this report. In addition, the spreadsheet automatically transfers the mass values and associated errors to the appropriate cells in section 3 of the spreadsheet.

Section 4 of the spreadsheet calculates the Burial Ground Record information for the various types of material that could potentially be present in a waste package. The spreadsheet automatically transfers the "Reportable Mass" value and "2X Error" value to the appropriate cells in section 4.

Looking at U-235 as an example, the element weight for the uranium material is equal to the reportable mass of U-235 since it is assumed that this is the only uranium isotope present in the $772 \mathrm{~F} 029$ waste stream.

The element weight including the $2 \mathrm{X}$ error is then calculated by adding the $2 \mathrm{X}$ error to the element weight,

Element Wt $(\mathrm{g})+2 \mathrm{X}$ Error $(\mathrm{g})=4.630+1.389=6.019$

The associated low level waste distribution shown in section 5 of the spreadsheet is automatically calculated based upon the information entered in sections 1 and 2. More information on this distribution is given in Table 4. The "Reported Activity" values follow the appropriate rules set forth in Reference 4. As mentioned previously in section 3.0, if Co-60 is not detected, then the reported activity value for this nuclide is scaled to the Cs137 activity.

\subsection{CLAB 772F029 TRU Waste Spreadsheet Results}

The CLAB 772F029 TRU Waste Spreadsheet verification results are shown in Appendix 2.

\subsection{REFERENCES}

1. Black, J. E. Transuranic (TRU) Waste Characterization Plan for CLAB, TSD-WRS99-0239, Rev. 0, Savannah River Site, Aiken, SC 29808 (1999).

2. East, J. M. Specific Activities of 167 Common Accident Analysis Radionuclides (U). N-CLC-G-00040, Rev. 0, Savannah River Site, Aiken, SC 29808 (1996).

3. Knoll, G. F. Radiation Detection and Measurement, p. 132, John Wiley and Sons, New York (1979). 
4. Low Level, Hazardous, Mixed and PCB Waste Characterization Requirements, WSRC 1S Manual, Procedure 2.02, Rev. 4, Savannah River Site, Aiken, SC 29808 (1999).

\subsection{APPENDICES}

6.1 Appendix 1. CLAB TRU Waste Spreadsheet

6.2 Appendix 2. CLAB 772F029 TRU Spreadsheet 
Appendix 1

WSRC-TR-99-00414

Revision 0

November 1, 1999

Page 16

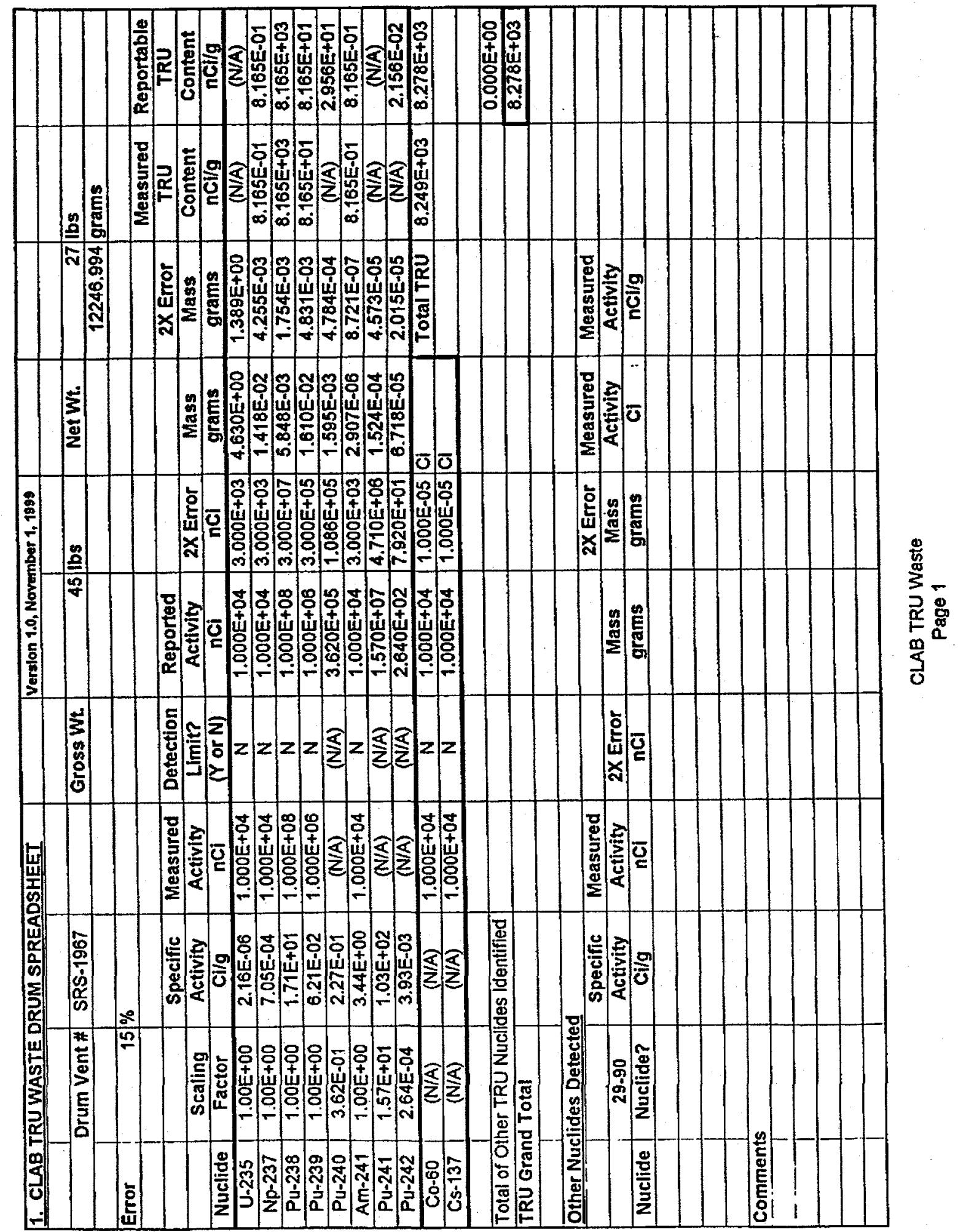


Appendix 1

WSRC-TR-99-00414

Revision 0

November 1, 1999

Page 17

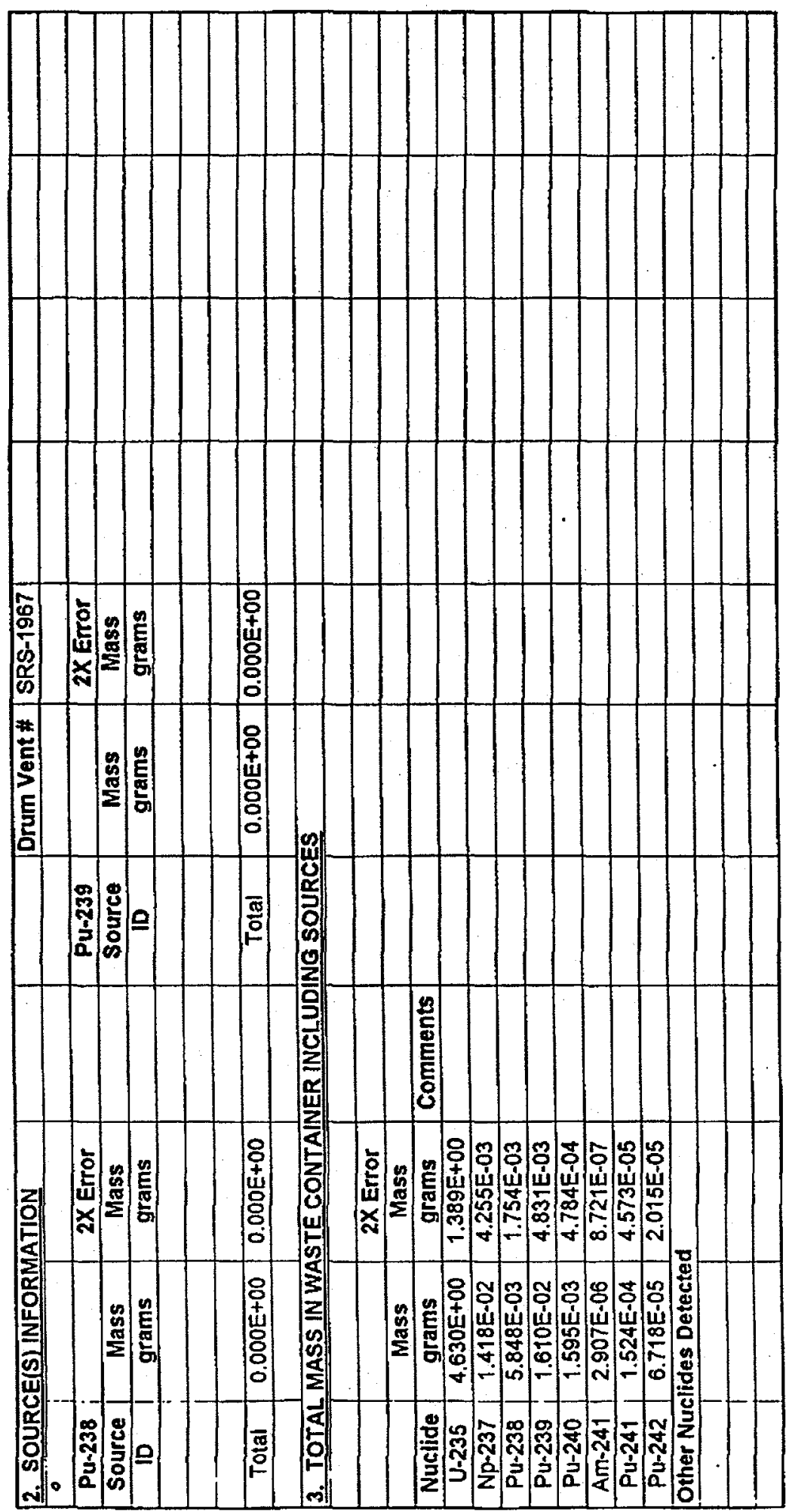

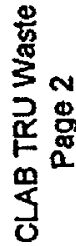


Appendix

WSRC-TR-99-00414

Revision 0

November 1, 1999

Page 18

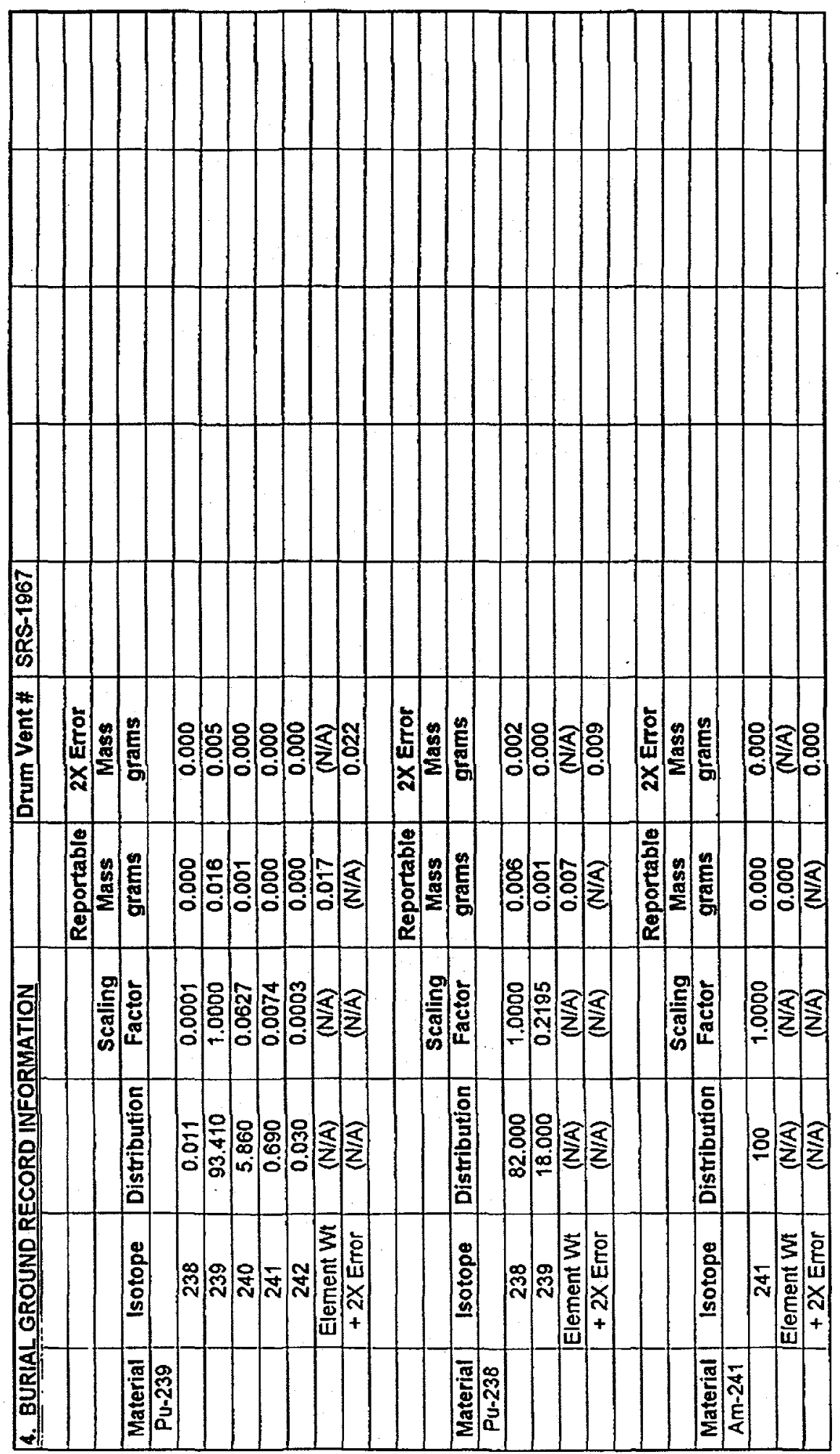

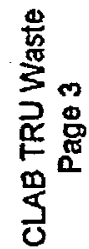


Appendix WSRC-TR-99-00414

Revision 0

November 1, 1999

Page 19

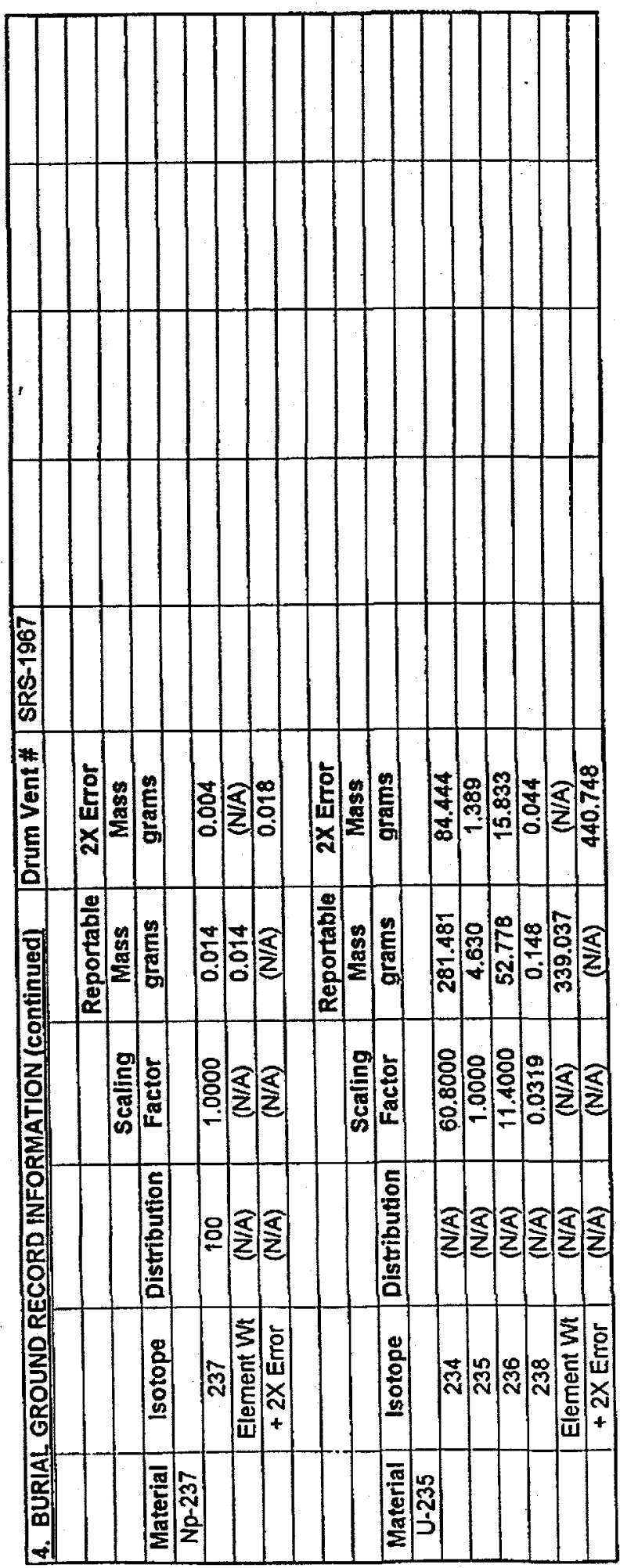

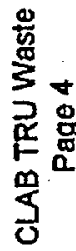


Appendix 1

WSRC-TR-99-00414

Revision 0

November 1, 1999

Page 20

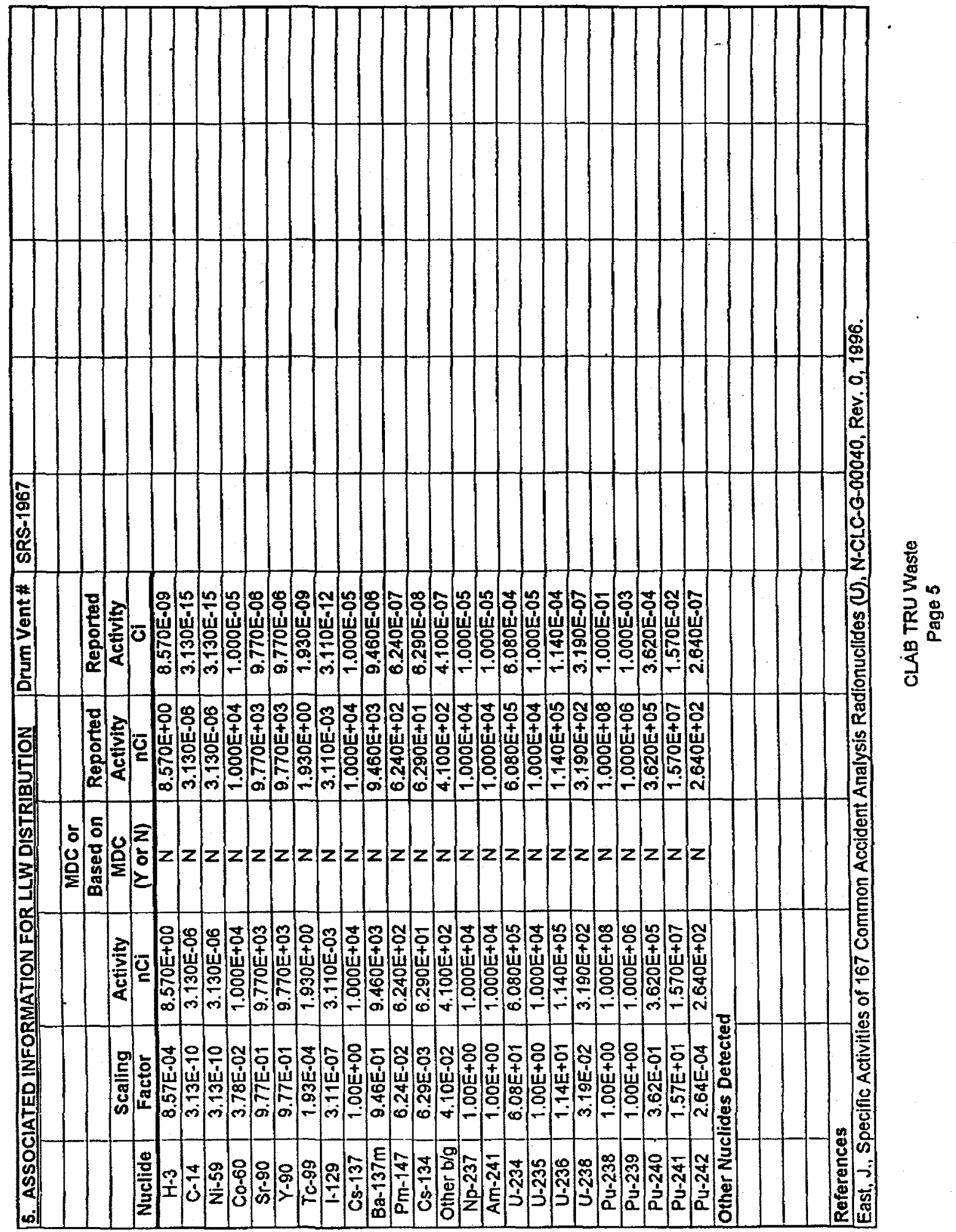




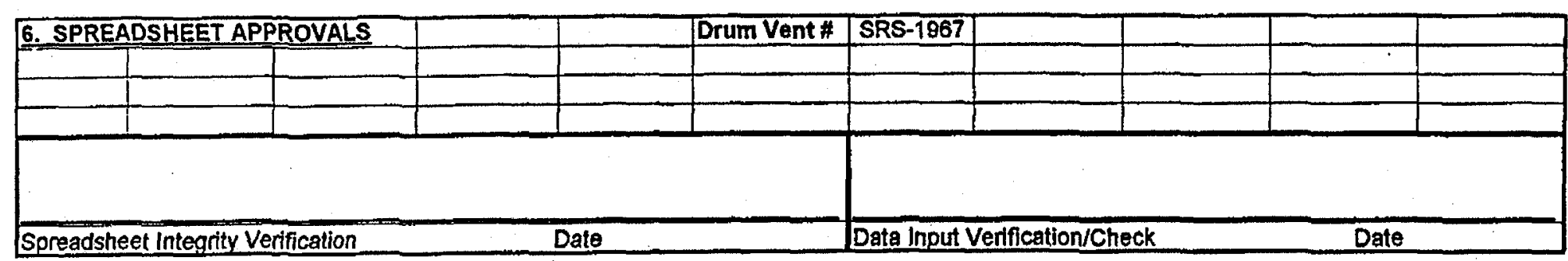

CLAB TRU Waste

Page 6

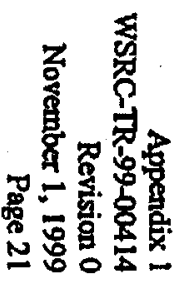


Appendix 2

WSRC-TR-99-00414

Revision 0

Novernber 1, 1999

Page 22

\begin{tabular}{|c|c|c|c|c|c|}
\hline & 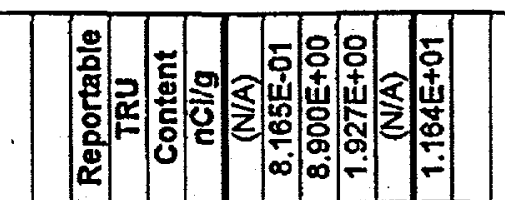 & 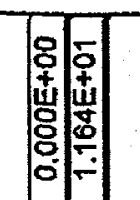 & & & \\
\hline & & & & & \\
\hline & 悉 & & 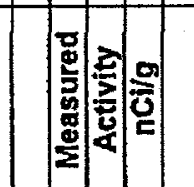 & & \\
\hline & 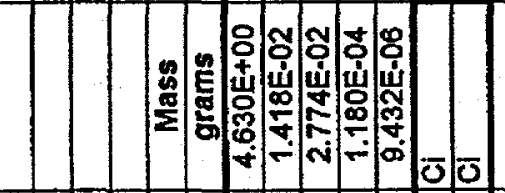 & & 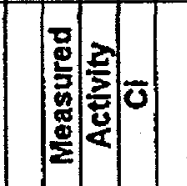 & & \\
\hline & 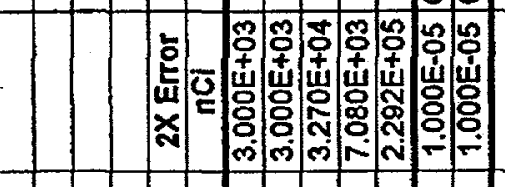 & & 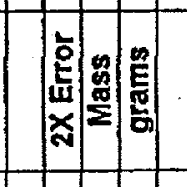 & & \\
\hline : & 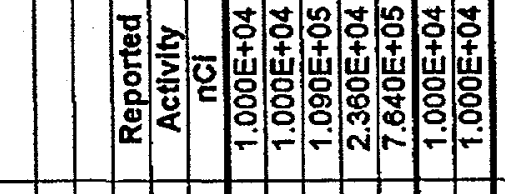 & & 路 & & \\
\hline 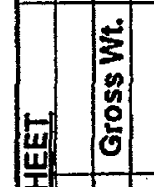 & 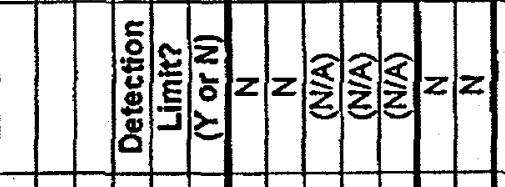 & & : & & \\
\hline : & 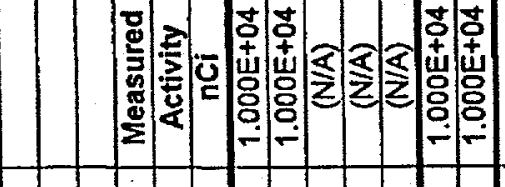 & & 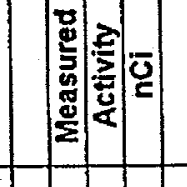 & & \\
\hline 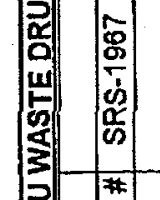 & : & $\mid$ & : & & \\
\hline 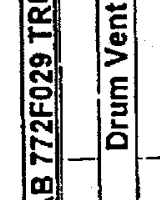 & H & 密: & 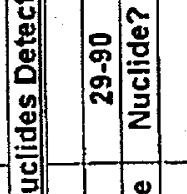 & & \\
\hline$\left[\begin{array}{ll}0 \\
\vdots \\
0\end{array}\right]$ & 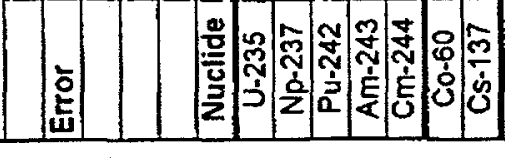 & $\mid$ & 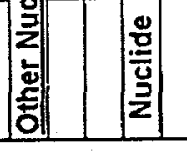 & & 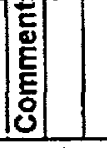 \\
\hline
\end{tabular}

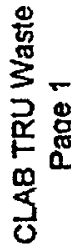


Appendix 2 WSRC-TR-99-00414

Revision 0

November 1, 1999

Page 23

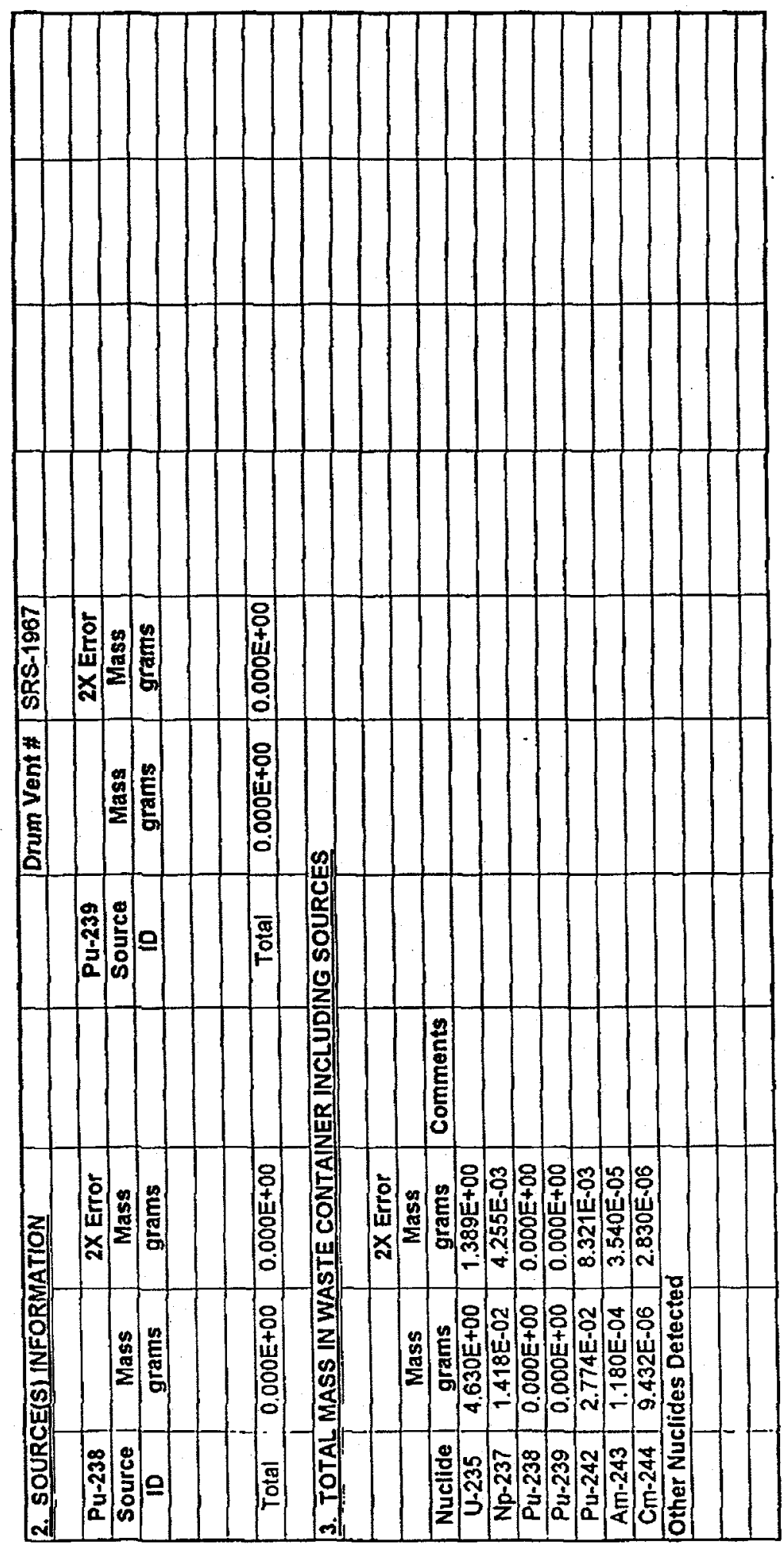

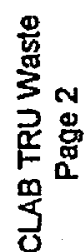


Appendix 2

WSRC-TR-99-00414

Revision 0

November 1, 1999

Page 24

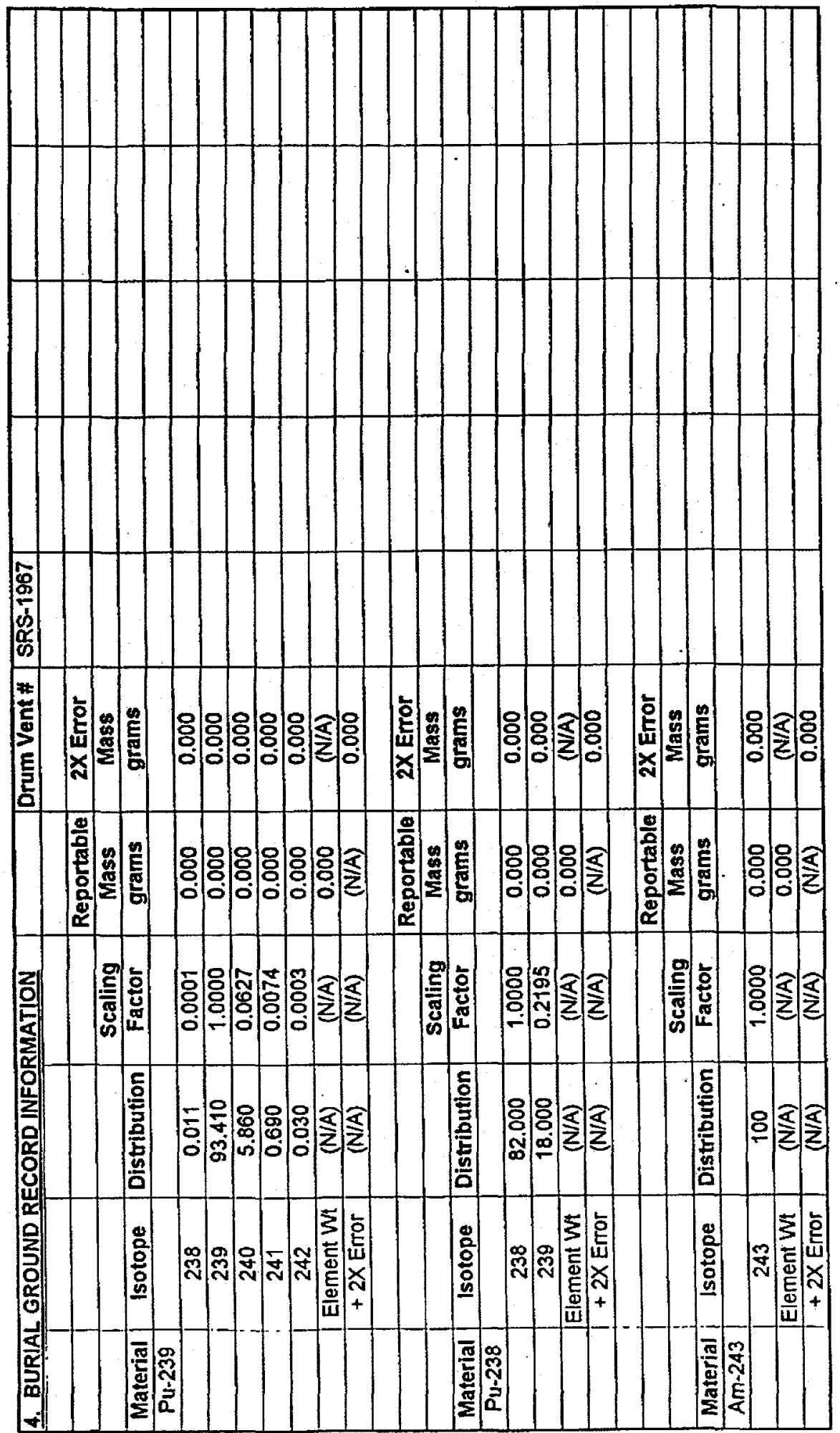

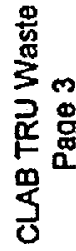


Appendix 2

WSRC-TR-99-00414

Revision 0

November 1. 1999

Page 25

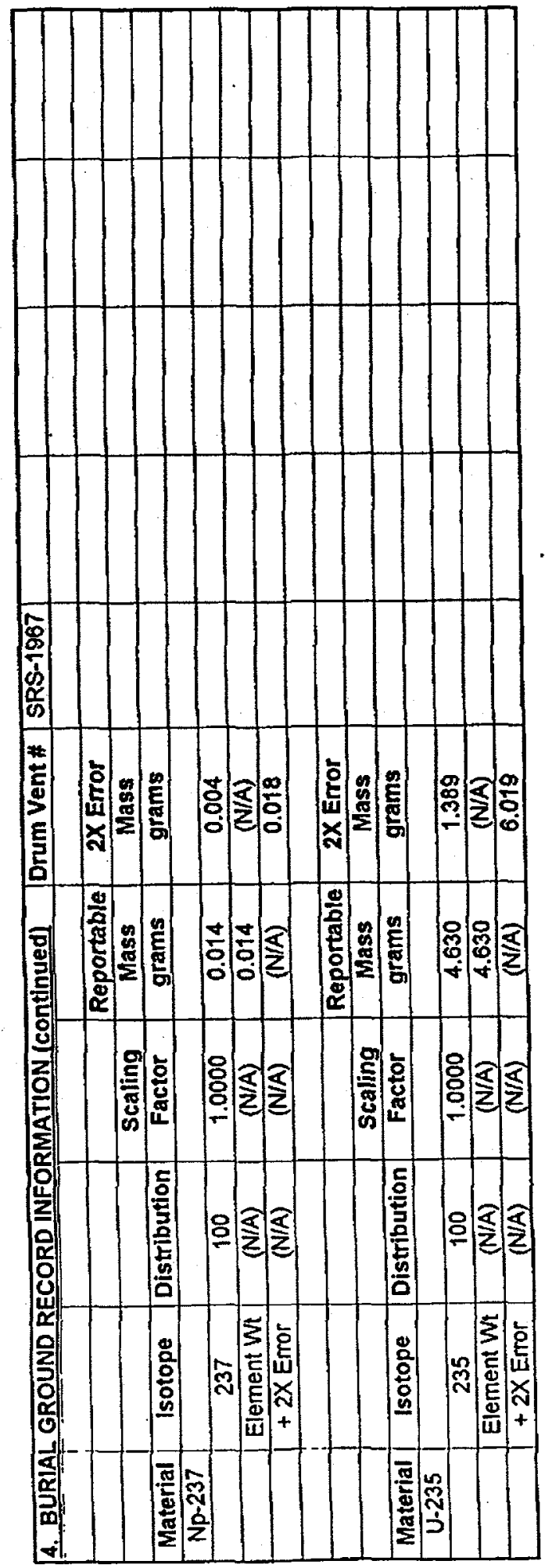

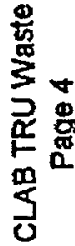




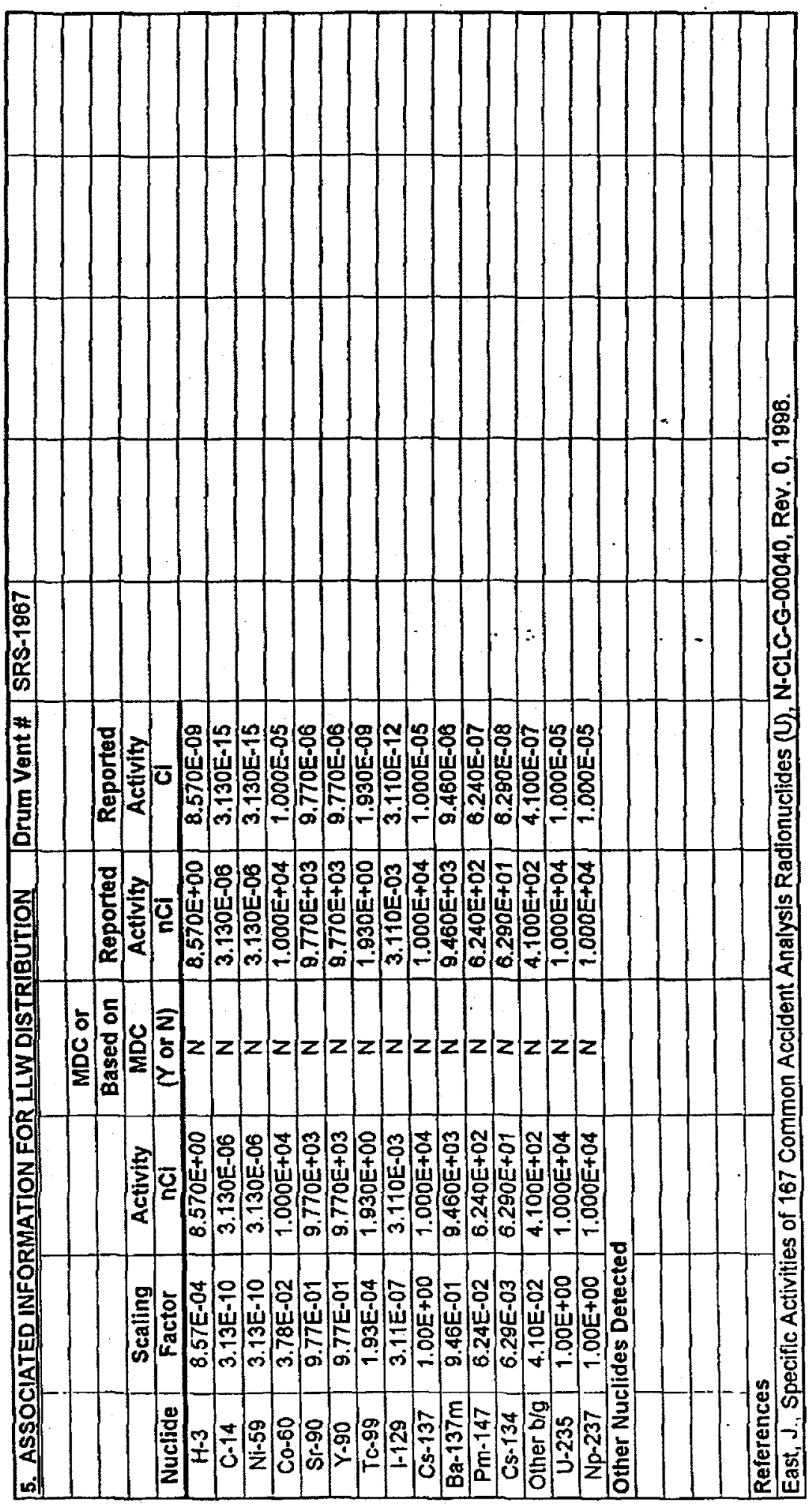


